\title{
Sensitivity to antifungals by Candida spp samples isolated from cases of chronic atrophic candidiasis (CAC)
}

\author{
L. C. Reinhardt (D), P. S. Nascente $^{b}$ (D), J. S. Ribeiro ${ }^{a}$ (D), V. B. S. Guimarães ${ }^{a}$ (D), A. Etges ${ }^{c}$ \\ and R. G. Lund ${ }^{a, b *}$ (D)
}

aPrograma de Pós-graduação em Odontologia - PPGO, Laboratório de Microbiologia Oral, Faculdade de Odontologia, Universidade Federal de Pelotas - UFPel, Rua Gonçalves Chaves, 457, Sala 702/3,

CEP 96015-560, Pelotas, RS, Brasil

\begin{abstract}
bPrograma de Pós-graduação em Bioquímica e Bioprospecção - PPGBBio, Departamento de Microbiologia e Parasitologia, Laboratório de Micologia, Universidade Federal de Pelotas - UFPel, Campus Universitário Capão do Leão, s/n, 96010-900, Capão do Leão, RS, Brasil

'Centro de Diagnóstico e Doenças da Boca - CDDB, Faculdade de Odontologia, Universidade Federal de Pelotas - UFPel, Rua Gonçalves Chaves, 457, Sala 607, CEP 96015-560, Pelotas, RS, Brasil

* e-mail: rafael.lund@gmail.com
\end{abstract}

Received: January 19, 2018 - Accepted: September 10, 2018 - Distributed: May 31, 2020

(With 2 figures)

\begin{abstract}
The treatment of choice for chronic atrophic candidiasis (CAC), also known as denture stomatitis, is topical antifungal therapy. This study aimed to isolate, identify, and assess the antifungal susceptibility of Candida species from mucosal sites in denture wearers with a diagnosis of CAC and determine the prevalence of associated variables. The sample consisted of 44 patients wearing complete or partial dentures who had a clinical diagnosis of CAC. Using sterile cotton swabs, specimens were collected from the oral mucosa of all patients and grown at $30^{\circ} \mathrm{C}$ for $48 \mathrm{~h}$ in CHROMagar Candida, as a means of isolating and screening the species. The complementary identification of the species was performed using the VITEK 2 automated system (BioMérieux), as well as the determination of their susceptibility to antifungal agents. Data were analyzed using the chi-square test. STATA 13.1 was used for statistical analysis $(\alpha=5 \%)$. Of 44 patients with CAC, 33 (75\%) had lesions classified as Newton type II. Yeasts were isolated in 38 cases. The most prevalent species was Candida albicans. None of the isolates were resistant to the antifungals tested. Our findings suggest that current indications for antifungal agents are appropriate. Also, antifungal susceptibility testing and proper fungal identification can help dentists to determine the optimal course of treatment for CAC.
\end{abstract}

Keywords: Candida, yeasts, denture stomatitis, antifungal, susceptibility.

\section{Sensibilidade a antifúngicos por amostras de Candida spp isoladas de casos de candidíase atrófica crônica (CAC)}

\section{Resumo}

O tratamento de escolha para candidíase atrófica crônica (CAC), também conhecida como estomatite protética, é a terapia antifúngica tópica. Este estudo teve como objetivo isolar, identificar e avaliar a susceptibilidade antifúngica de espécies de Candida de locais mucosos em portadores de prótese com diagnóstico de CAC e determinar a prevalência de variáveis associadas. A amostra consistiu em 44 pacientes portadores de próteses completas ou parciais que tiveram um diagnóstico clínico de CAC. Usando swab estéril, foram coletados espécimes da mucosa oral de todos os pacientes e cultivados a $30^{\circ} \mathrm{C}$ durante $48 \mathrm{~h}$ em CHROMagar Candida, como forma de isolamento e triagem das espécies. A identificação complementar das espécies foi realizada no sistema automatizado VITEK 2 (BioMérieux), bem como a determinação da susceptibilidade delas a agentes antifúngicos. Os dados foram analisados usando o teste do qui-quadrado. O STATA 13.1 foi utilizado para análise estatística $(\alpha=5 \%)$. Dos 44 pacientes com CAC, $33(75 \%)$ apresentaram lesões classificadas como Newton tipo II. As leveduras foram isoladas em 38 casos. A espécie mais prevalente foi Candida albicans. Nenhum dos isolados foi resistente aos antifúngicos testados. Nossas descobertas sugerem que as indicações atuais para os agentes antifúngicos são apropriadas. Além disso, testes de susceptibilidade antifúngicos e identificação fúngica adequada podem ajudar os dentistas a determinar o curso ótimo de tratamento para CAC.

Palavras-chave: Candida, leveduras, estomatite protética, antifúngico, susceptibilidade. 


\section{Introduction}

Oral candidiasis is a common chronic condition that affects a large proportion of the population, especially denture wearers. Chronic atrophic candidiasis (CAC), also known as denture stomatitis, is the most common manifestation of Candida infection and affects more than $65 \%$ of individuals wearing maxillary partial dentures (Gonçalves et al., 2013; Chambo-Filho et al., 2014; Santos et al., 2016; Punnia-Moorthy, 2019). CAC is usually detected during intraoral examination and characterized as inflammation and erythema of the oral mucosal surfaces covered by the dental prosthesis (Armstrong et al., 2016).

The diagnosis of CAC is established by clinical examination, but the use of microbiological methods as a complementary diagnostic tool, such as the oral smear method, is advisable (Lund et al., 2010). Available methods for the identification of Candida species include polymerase chain reaction (PCR), CHROMagar Candida medium (based on colony color), and new automated methods that allow simultaneous testing of antifungal susceptibility (Alam et al., 2014; Tellapragada et al., 2014; Aydemir et al., 2017; Brandolt et al., 2017).

The treatment of choice for CAC is topical antifungal therapy, although systemic therapy may be required in some cases. Patients should also be advised to always remove dentures before going to bed, soak them in sodium hypochlorite or sodium bicarbonate solution, and clean them thoroughly (Andrade et al., 2013; Emami et al., 2014). The most commonly used antifungal agents for the treatment of CAC are polyene antifungals (nystatin), which alter the permeability of the fungal cytoplasmic membrane, azole antifungals (miconazole, ketoconazole, itraconazole, and fluconazole), which bind to the membrane and destroy its constituent components, rendering it nonfunctional, and DNA analogs (flucytosine), which interfere with fungal nucleic acid synthesis (Skupien et al., 2013; Lalla and Dongari-Bagtzoglou, 2014; Tay et al., 2014). For systemic therapy, intravenous amphotericin B can be administered in extreme cases; however, it is an extremely strong medication associated with immediate adverse effects, such as fever, chills, and nausea (Costa et al., 2013). Fluconazole, administered orally or intravenously, can provide a viable alternative, especially in cases of disseminated candidiasis, due to its high efficacy and low toxicity. Miconazole is also available in patch form (Kossioni, 2011).

Given the often prolonged and recurrent nature of traditional antifungal therapy, the strains become resistant to these agents. However, it is unclear whether the demographic and clinical profile of patients with oral candidiasis receiving these agents is similar or varies depending on the type of antifungal prescribed. In addition, it is important to isolate, identify, and test the antifungal drug susceptibility of causative agents involved in CAC (Skupien et al., 2013; Gleiznys et al., 2015; Patil et al., 2015; Warnakulasuriya, 2019).
A previous study performed by our group provided first epidemiology data on frequency of chronic atrophic candidiasis (CAC) and the prevalence of certain infection-associated variables to this disease (Lund et al., 2010). However this study addressed to other variables associated to $\mathrm{CAC}$, and yeasts were identified using traditional phenotypic tests [micromorphology, microculture in agar cornmeal, chromogenic medium (CHROM Agar Candida ${ }^{\circledR}$ ) and growth in hypertonic broths], but these data were not confirmed in that occasion by a biochemical automated method $\left(\right.$ VITEK $\left.^{\circledR} 2\right)$. Moreover, the first study did not assess the susceptibility of the isolates of Candida and some variables associated to CAC were not taken into consideration, as the categorization of the status of $\mathrm{CAC}$ in patients according to the Newton classification (Newton, 1962).

Considering this and the lack of data on these topics taken in the present work, this study aimed to assess the prevalence of Candida spp. isolated from patients with chronic atrophic candidiasis and some variables associated to $\mathrm{CAC}$, as well as to determine the susceptibility of these isolates by a biochemical automated method.

\section{Materials and Methods}

Participants were recruited among adult patients seeking dental care at the Center for Diagnosis of Oral Diseases of the Universidade Federal de Pelotas (UFPel) School of Dentistry, southern Brazil, from April 2014 to March 2015. The study was approved by the Research Ethics Committee of the institution (protocol no. 033/2006) and conducted in accordance with the provisions of the Declaration of Helsinki. Written informed consent was obtained from all individual participants prior to their inclusion in the study.

Eligible participants were all patients aged $\geq 18$ years wearing complete or partial dentures who had a clinical diagnosis of CAC and were able to understand and complete the study questionnaire. The clinical diagnosis of CAC was based on intraoral findings of diffuse or focal, erythematous, micropapular lesions in the palatal mucosa and/or on the dorsum of the tongue that were clinically consistent with CAC. Exclusion criteria were the presence of other oral conditions that preclude immediate mycological diagnosis and absence of clinical manifestations consistent with CAC.

All patients who agreed to participate in the study underwent an intraoral examination for clinical manifestations of CAC and then completed a standardized questionnaire. A single examiner, who had been previously trained and calibrated by an oral pathologist, performed all examinations under a standard operatory light using a mouth mirror, wooden tongue depressors, and gauze pads. The status of CAC was categorized according to the Newton classification (Newton, 1962), which divides the condition into three types based on the clinical appearance of the lesions: type I - pinpoint hyperemia or 
localized inflammation, with small areas of inflammation usually found around the minor palatal salivary glands; type II - diffuse hyperemia characterized by generalized inflammation of the entire denture-bearing area and a smooth mucosal surface; and type III - inflammatory nodular/papillary hyperplasia usually on the central hard palate and the alveolar ridge.

The following variables were considered in the analysis: clinical appearance of the lesions (Newton classification); site of involvement (palate, tongue, or both); systemic disease (presence or absence); type of denture (complete, partial, or both); length of denture use ( $\leq 1$ year, 2-5 years, 6-10 years, or $>10$ years); compliance with denture hygiene instructions (yes or no); removal of dentures at night (yes or no); history of antifungal therapy (yes or no); and current smoking (yes or no).

Using sterile cotton swabs, specimens were collected from the oral mucosa of all selected patients by gently rubbing the affected mucosa (Lund et al., 2010). Cultures were grown at $30{ }^{\circ} \mathrm{C}$ for $48 \mathrm{~h}$ in Petri dishes containing CHROMagar Candida medium (Probac do Brasil, São Paulo, SP, Brazil). The material was then frozen for later identification.

Species were identified using the VITEK 2 Compact automated system (BioMérieux, Brazil), and VITEK 2 YST ID cards were used for fungal identification. The VITEK 2 system is integrated with the Myla software (BioMérieux, Brazil), which combines information on a central dashboard for monitoring of sample preparation and analysis. The loaded cards were simultaneously placed in VITEK 2, a fully automated system composed of traditional biochemical tests for yeast identification.

The Candida spp. isolates were tested for antifungal susceptibility in the VITEK 2 system using the AST-YS07 card (BioMérieux, Brazil), which measures susceptibilities to flucytosine, fluconazole, voriconazole, amphotericin B, caspofungin, and micafungin.

Statistical analysis was performed using STATA, version 13.1. Variables were tested for their association with the three Newton types using Pearson's chi-square test. The level of significance was set at $5 \%(P \leq 0.05)$.

\section{Results}

A total of 44 patients with a clinical diagnosis of CAC were eligible and agreed to participate in the study. Specimens were collected from all 44 patients, but yeasts were isolated in 38 cases. The remaining 6 cases did not exhibit growth after $48 \mathrm{~h}$ of incubation.

The characteristics of the sample are shown in Table 1. The most prevalent form of CAC was Newton type II (33 of 44 patients, $75.0 \%$ ). Regarding denture use, most patients $(63.6 \%)$ wore complete dentures, and only 1 patient $(2.3 \%)$ had been wearing dentures for $\leq 1$ year. Only 1 patient $(2.3 \%)$ reported not complying with denture hygiene instructions, while $17(38.6 \%)$ reported not removing the denture at night. Twenty patients $(45.4 \%)$ had received prior antifungal therapy, and 10 patients $(22.7 \%)$ were smokers.

The palate was the most common site of involvement, accounting for 43 cases $(97.7 \%)$. In 1 case $(2.3 \%)$, the lesion was located on the upper alveolar ridge. Regarding the presence of systemic diseases, 15 patients $(34.1 \%)$ reported having a systemic disease (Table 1).

The most common diseases were hypertension, diabetes, and depression; all patients reported controlling the disease through medication.

Of the 38 Candida spp. isolates, 34 grew only one species, while 4 grew two species - overall, the most prevalent species was Candida albicans (Figure 1).

None of the isolates were resistant to the antifungals tested (Table 2).

Six Candida spp. isolates (15.8\%) were associated with type I lesions, 29 (76.3\%) with type II lesions, and $3(7.9 \%)$ with type III lesions (Figure 2).

Table 1. Characteristics of the sample ( $n=44$ patients).

\begin{tabular}{lcr}
\hline \multicolumn{1}{c}{ Variable } & $n$ & \% \\
\hline Newton type & 8 & 18.2 \\
I & 33 & 75.0 \\
II & 3 & 6.8 \\
III & & \\
Type of denture & 28 & 63.6 \\
$\quad$ Complete denture & 6 & 13.6 \\
Removable partial denture & 10 & 22.7 \\
Both & & \\
Length of denture use (years) & 1 & 2.3 \\
$\quad \leq 1$ & 9 & 20.5 \\
2 to 5 & 20 & 45.5 \\
6 to 10 & 14 & 31.8 \\
$>10$ & &
\end{tabular}

Compliance with denture hygiene instructions

Yes

No

1

Removal of dentures at night

Yes

61.4

No

$17 \quad 38.6$

Prior antifungal therapy

Yes

$20 \quad 45.5$

No

$24 \quad 54.6$

Current smoking

Yes

$\begin{array}{ll}10 & 22.7\end{array}$

No

$34 \quad 77.3$

Site of involvement

Palate

$\begin{array}{ll}43 & 97.7\end{array}$

Tongue

Both

12.3

Systemic disease

Present

15

34.1

Absent 


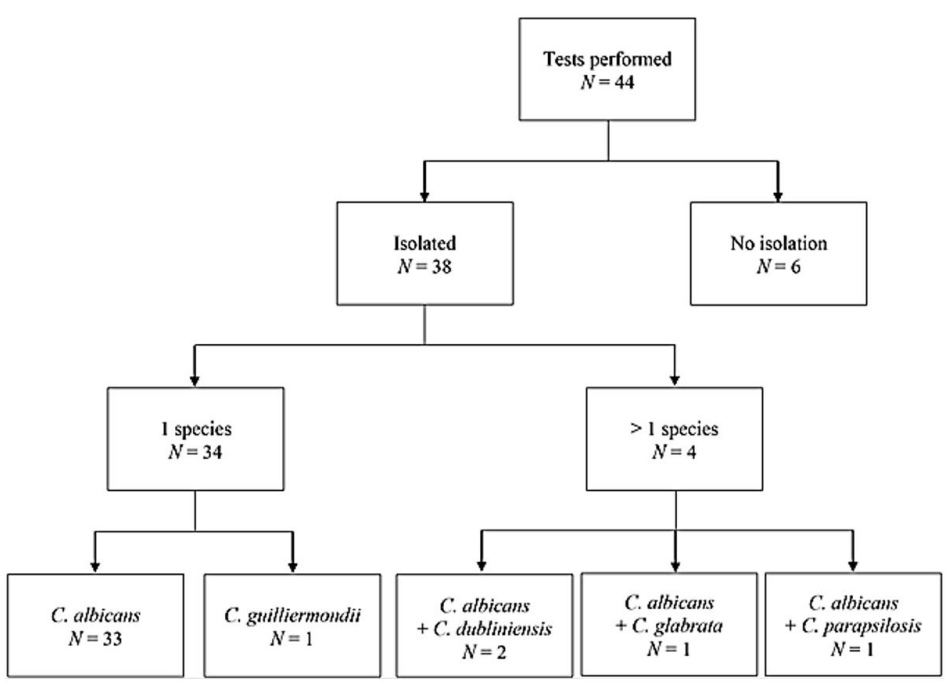

Figure 1. Flowchart of tests performed and species identified.

Table 2. Isolates and susceptibility to the antifungals tested.

\begin{tabular}{lcc}
\hline \multicolumn{1}{c}{ Fungus } & $n$ & $\mathbf{\%}$ \\
\hline C. albicans & & \\
Resistant & 0 & 0 \\
Susceptible & 37 & 100 \\
C. dubliniensis & & \\
Resistant & 0 & 0 \\
Susceptible & 2 & 100 \\
C. glabrata & & \\
Resistant & 0 & 0 \\
Susceptible & 1 & 100 \\
C. parapsilosis & & \\
Resistant & 0 & 0 \\
Susceptible & 1 & 100 \\
C. guilliermondii & & \\
Resistant & 0 & 0 \\
Susceptible & 1 & 100 \\
\hline
\end{tabular}

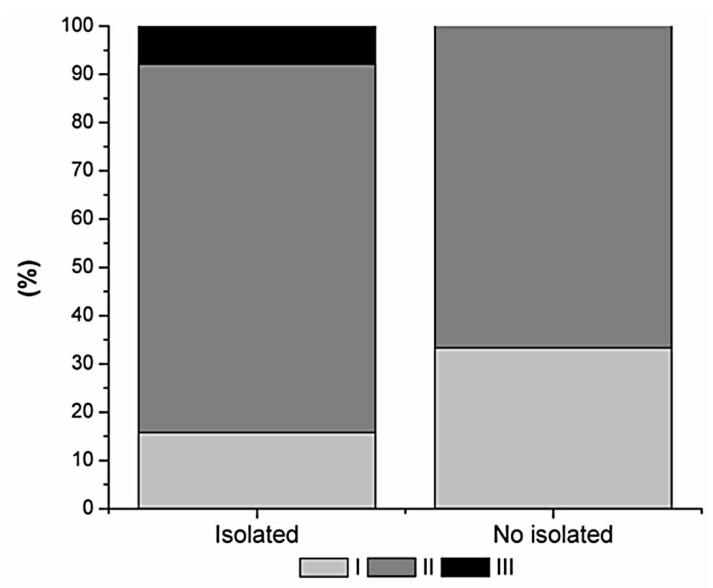

Figure 2. Association between isolation and Newton types I, II, and III lesions.

Table 3 shows the associations between Newton types and other variables of interest. None of the associations were statistically significant.

\section{Discussion}

Among the several clinical forms of candidiasis, CAC is considered one of the most ubiquitous of all opportunistic infections, frequently co-occurring with angular cheilitis, at the labial commissures, or in the "kissing lesion" of the dorsum of the tongue (Rao, 2012; Chambo-Filho et al., 2014; Brandolt et al., 2017; Hellstein \& Marek, 2019). Studies suggest that women are more affected than men; however, it is known that women are more likely to seek medical attention and that incidence increases with advancing age, i.e., older adults have a higher prevalence of this condition, particularly due to

denture use and difficulties in oral hygiene (Rao, 2012; Chambo-Filho et al., 2014).

Candidiasis is often associated with local conditions, such as other oral lesions (traumatic fibromas, aphthous stomatitis, carcinoma, etc.), or systemic diseases, such as diabetes, cardiovascular disorders, depression, and immunosuppression (Lund et al., 2010; Brandolt et al., 2017; Hellstein \& Marek, 2019). In the present study, most patients had no systemic diseases or other oral lesions.

Yeasts of the species C. albicans account for $80-90 \%$ of all cases of CAC, although other species can also be implicated, such as C. tropicalis, C. parapsilosis, C. glabrata, C. stellatoidea, C. guilliermondii, and C. krusei (Lund et al., 2010; Costa et al., 2013; Alam et al., 2014; Hellstein \& Marek, 2019; Punnia-Moorthy, 2019). In the present study, more than $90 \%$ of isolates were identified 
Reinhardt, L. C. et al.

Table 3. Association between Newton types and the variables of interest ( $n=44$ patients).

\begin{tabular}{|c|c|c|c|c|c|c|c|}
\hline \multirow{3}{*}{ Variable } & \multicolumn{6}{|c|}{ Newton type } & \multirow{3}{*}{$P$-value* } \\
\hline & \multicolumn{2}{|c|}{ I } & \multicolumn{2}{|c|}{ II } & \multicolumn{2}{|c|}{ III } & \\
\hline & $n$ & $\%$ & $n$ & $\%$ & $n$ & $\%$ & \\
\hline Type of denture & & & & & & & 0.534 \\
\hline Complete denture & 5 & 17.9 & 22 & 78.6 & 1 & 3.6 & \\
\hline RPD & 2 & 33.3 & 3 & 50.0 & 1 & 16.7 & \\
\hline Both & 1 & 10.0 & 8 & 80.0 & 1 & 10.0 & \\
\hline Length of denture use & & & & & & & 0.134 \\
\hline$\leq 1$ years & 1 & 100.0 & 0 & 0.0 & 0 & 0.0 & \\
\hline 2 to 5 years & 2 & 22.2 & 7 & 77.8 & 0 & 0.0 & \\
\hline 6 to 10 years & 5 & 25.0 & 14 & 70.0 & 1 & 5.0 & \\
\hline$>10$ years & 0 & 0.0 & 12 & 85.7 & 2 & 14.3 & \\
\hline Daily hygiene & & & & & & & 0.843 \\
\hline No & 0 & 0.0 & 1 & 100.0 & 0 & 0.0 & \\
\hline Yes & 8 & 18.6 & 32 & 74.4 & 3 & 7.0 & \\
\hline Removal of dentures at night & & & & & & & 0.206 \\
\hline Yes & 6 & 22.2 & 18 & 66.7 & 3 & 11.1 & \\
\hline No & 2 & 11.8 & 15 & 88.2 & 0 & 0.0 & \\
\hline Prior antifungal therapy & & & & & & & 0.140 \\
\hline No & 5 & 20.8 & 19 & 79.2 & 0 & 0.0 & \\
\hline Yes & 3 & 15.0 & 14 & 70.0 & 3 & 15.0 & \\
\hline Smoking & & & & & & & 0.879 \\
\hline No & 6 & 17.7 & 26 & 76.5 & 2 & 5.9 & \\
\hline Yes & 2 & 20.0 & 7 & 70.0 & 1 & 10.0 & \\
\hline Affected site & & & & & & & 0.843 \\
\hline Palate & 8 & 18.6 & 32 & 74.4 & 3 & 7.0 & \\
\hline Both & 0 & 0.0 & 1 & 100.0 & 0 & 0.0 & \\
\hline Systemic disease & & & & & & & 0.292 \\
\hline Present & 4 & 26.7 & 11 & 73.3 & 0 & 0.0 & \\
\hline Absent & 4 & 13.8 & 22 & 75.9 & 3 & 10.3 & \\
\hline
\end{tabular}

$\mathrm{RPD}=$ removable partial denture. $*$ Pearson's chi-square test.

as $C$. albicans, either as the sole species identified or as one of the species involved.

The most common Newton classification of CAC is type II, which corresponds to an area of diffuse erythema on the palate (Newton, 1962; Chambo-Filho et al., 2014), consistent with the higher prevalence of type II lesions observed in the present study. This distribution most likely occurs because patients with CAC often wear complete dentures, which entails a larger surface area of contact between the prosthesis and palate. However, when the Newton classification was cross-referenced with the other variables of interest, no statistically significant differences were found for any of the individual-level variables.

Several methods are available for the identification of Candida species. In the present study, we used the VITEK 2 system, in which an electronic workflow is generated automatically, ensuring complete sample traceability from beginning to end. This system was also used to test the isolates for susceptibility to several antifungals (flucytosine, fluconazole, voriconazole, amphotericin B, caspofungin, and micafungin); as the results show, none of the isolates were resistant to the antifungals tested.
The treatment of choice for CAC is topical antifungal therapy, which leads to regression of the disease in most cases. However, in some situations, remission is difficult to achieve. The major challenges observed are resistance to antifungal agents, dependence on patient adherence to treatment, which is often hindered by advanced age, dissolution of orally administered agents, and cleansing of the oral cavity by saliva (Lalla and Dongari-Bagtzoglou, 2014; Ohshima et al., 2018). These factors contribute to reduced concentration of topical antifungals, which often leads to protracted treatment and high recurrence rates (Mima et al., 2012; Maciag et al., 2014). All patients included in this study were or had been receiving topical antifungal therapy and were kept under periodic follow-up.

Exposure to subtherapeutic concentrations is believed to be one of the factors responsible for the increased pathogenicity of Candida species (Copping et al., 2005; Sanita et al., 2013). Potential increases in pathogenicity of species less virulent than $C$. albicans, but resistant to fluconazole - such as C. krusei - is also a concern (Messer et al., 2006). In addition, clinicians must take into account that systemic antifungal therapy, although 
effective, is unable to eliminate the microorganisms that have colonized the surface of the dental prosthesis (Shapiro et al., 2011; Javed et al., 2014).

The efficacy of treatment depends on a variety of factors, including patient cooperativeness, proper dosage, and proper treatment duration. Therefore, the optimal treatment strategy for $\mathrm{CAC}$ must be chosen on a case-by-case basis (Chambo-Filho et al., 2014; Kesic et al., 2014). An alternative for better solution of cases of CAC is to introduce the use of the antifungals tested in the VITEK 2 system as part of the routine service in laboratories, medical centers, clinics or hospitals.

In conclusion, the most prevalent form of CAC in our sample was Newton type II, and the most prevalent species was $C$. albicans. Complete denture wearers were the most commonly affected group, and the palate was the predominant site of involvement. None of the identified species were resistant to the antifungals tested. These findings suggest that current indications for these antifungal agents are appropriate and that antifungal susceptibility testing and proper fungal identification can help dentists determine the optimal course of treatment for CAC.

\section{References}

ALAM, M.Z., ALAM, Q., JIMAN-FATANI, A., KAMAL, M.A., ABUZENADAH, A.M., CHAUDHARY, A.G., AKRAM, M. and HAQUE, A., 2014. Candida identification: a journey from conventional to molecular methods in medical mycology. World Journal of Microbiology \& Biotechnology, vol. 30, no. 5, pp. 1437-1451. http://dx.doi.org/10.1007/s11274-013-1574-z. PMid:24379160.

ANDRADE, M.C., RIBEIRO, A.P., DOVIGO, L.N., BRUNETTI, I.L., GIAMPAOLO, E.T., BAGNATO, V.S. and PAVARINA, A.C., 2013. Effect of different pre-irradiation times on curcuminmediated photodynamic therapy against planktonic cultures and biofilms of Candida spp. Archives of Oral Biology, vol. 58, no. 2, pp. 200-210. http://dx.doi.org/10.1016/j.archoralbio.2012.10.011. PMid:23153629.

ARMSTRONG, A.W., BUKHALO, M. and BLAUVELT, A., 2016. A clinician's guide to the diagnosis and treatment of candidiasis in patients with psoriasis. American Journal of Clinical Dermatology, vol. 17, no. 4, pp. 329-336. http://dx.doi. org/10.1007/s40257-016-0206-4. PMid:27435194.

AYDEMIR, Ö., TAYFURDEMIRAY, M.K., AYDEMIR, Y. and ALTINDIŞ, M., 2017. Emerge of non-albicans Candida species; evaluation of Candida species and antifungal susceptibilities according to years. Biomedical Research, vol. 28, no. 4, pp. 970-938.

BRANDOLT, T.M., KLAFKE, G.B., GONÇALVES, C.V., BITENCOURT, L.R., MARTINEZ, A.M., MENDES, J.F., MEIRELES, M.C. and XAVIER, M.O., 2017. Prevalence of Candida spp. in cervical-vaginal samples and the in vitro susceptibility of isolates. Brazilian Journal of Microbiology, vol. 48, no. 1, pp. 145-150. http://dx.doi.org/10.1016/j.bjm.2016.09.006. PMid:27756539.

CHAMBO-FILHO, A., SOUZA FILHO, J.B., PIGNATON, C.C., ZON, I., FERNANDES, A.S. and CARDOSO, L.Q., 2014. Chronic mucocutaneous candidiasis: a case with exuberant cutaneous horns in nipples. Anais Brasileiros de Dermatologia, vol. 89, no. 4, pp. 641-644. http://dx.doi.org/10.1590/abd18064841.20143020. PMid:25054753.

COPPING, V.M., BARELLE, C.J., HUBE, B., GOW, N.A., BROWN, A.J. and ODDS, F.C., 2005. Exposure of Candida albicans to antifungal agents affects expression of SAP2 and SAP9 secreted proteinase genes. The Journal of Antimicrobial Chemotherapy, vol. 55, no. 5, pp. 645-654. http://dx.doi.org/10.1093/ jac/dki088. PMid:15820985.

COSTA, A.C., PEREIRA, C.A., JUNQUEIRA, J.C. and JORGE, A.O., 2013. Recent mouse and rat methods for the study of experimental oral candidiasis. Virulence, vol. 4, no. 5, pp. 391-399. http://dx.doi.org/10.4161/viru.25199. PMid:23715031.

EMAMI, E., KABAWAT, M., ROMPRE, P.H. and FEINE, J.S., 2014. Linking evidence to treatment for denture stomatitis: a meta-analysis of randomized controlled trials. Journal of Dentistry, vol. 42, no. 2, pp. 99-106. http://dx.doi.org/10.1016/j. jdent.2013.11.021. PMid:24316341.

GLEIZNYS, A., ZDANAVIČIENĖ, E. and ŽILINSKAS, J., 2015. Candida albicans importance to denture wearers. A literature review. Stomatologija, vol. 17, no. 2, pp. 54-66. PMid:26879270.

GONÇALVES, L.S., JÚNIOR, A.S., FERREIRA, S.M., SOUSA, C.O., FONTES, T.V., VETTORE, M.V. and TORRES, S.R., 2013. Factors associated with specific clinical forms of oral candidiasis in HIV-infected Brazilian adults. Archives of Oral Biology, vol. 58, no. 6, pp. 657-663. http://dx.doi.org/10.1016/j. archoralbio.2012.10.007. PMid:23123068.

HELlSTEIN, J.W. and MAREK, C.L., 2019. Candidiasis: red and white manifestations in the oral cavity. Head and neck Pathology, vol. 29, no. 1, pp. 1-8.

KESIĆ L., DELIC, R., MIHAILOVIC, D., PETROVIC, M.S. and DELIC, T.D., 2014. Morphologic and morphometric analysis of alternations in the oral cavity caused by Candida albicans-experimental work. Medicinski Pregled, vol. 67, no. 5-6, pp. 149-153. http://dx.doi.org/10.2298/MPNS1406149K. PMid:25033573.

KOSSIONI, A.E., 2011. The prevalence of denture stomatitis and its predisposing conditions in an older Greek population. Gerodontology, vol. 28, no. 2, pp. 85-90. http://dx.doi.org/10.1111/ j.1741-2358.2009.00359.x. PMid:20082642.

JAVED, F., SAMARANAYAKE, L.P. and ROMANOS, G.E., 2014. Treatment of oral fungal infections using antimicrobial photodynamic therapy: a systematic review of currently available evidence. Photochemical \& Photobiological Sciences, vol. 13, no. 5, pp. 726-734. http://dx.doi.org/10.1039/C3PP50426C. PMid:24686309.

LALLA, R.V. and DONGARI-BAGTZOGLOU, A., 2014. Antifungal medications or disinfectants for denture stomatitis. Evidence-Based Dentistry, vol. 15, no. 2, pp. 61-62. http://dx.doi. org/10.1038/sj.ebd.6401032. PMid:24971864.

LUND, R.G., SILVA NASCENTE, P., ETGES, A., RIBEIRO, G.A., ROSALEN, P.L. and DEL PINO, F.A., 2010. Occurrence, isolation and differentiation of Candida spp. and prevalence of variables associated to chronic atrophic candidiasis. Mycoses, vol. 53, no. 3, pp. 232-238. http://dx.doi.org/10.1111/j.14390507.2009.01697.x. PMid:19389071.

MACIAG, J., OSMENDA, G., NOWAKOWSKI, D., WILK, G., MACIĄG, A., MIKOŁAJCZYK, T., NOSALSKI, T., SAGAN, A., FILIP, M., DRÓŻDŻ, M., LOSTER, J., GUZIK, T.J. and CZEŚNIKIEWICZ-GUZIK, M., 2014. Denture-related 
stomatitis is associated with endothelial dysfunction. BioMed Research International, vol. 2014, pp. 474016. http://dx.doi. org/10.1155/2014/474016. PMid:25045683.

MESSER, S.A., DIEKEMA, D.J., BOYKEN, L., TENDOLKAR, S., HOLLIS, R.J. and PFALLER, M.A., 2006. Activities of micafungin against 315 invasive clinical isolates of fluconazoleresistant Candida spp. Journal of Clinical Microbiology, vol. 44, no. 2, pp. 324-326. http://dx.doi.org/10.1128/JCM.44.2.324326.2006. PMid: 16455878 .

MIMA, E.G., VERGANI, C.E., MACHADO, A.L., MASSUCATO, E.M., COLOMBO, A.L., BAGNATO, V.S. and PAVARINA, A.C., 2012. Comparison of photodynamic therapy versus conventional antifungal therapy for the treatment of denture stomatitis: a randomized clinical trial. Clinical Microbiology and Infection, vol. 18 , no. 10 , pp. 380-388. http://dx.doi.org/10.1111/j.14690691.2012.03933.x. PMid:22731617.

NEWTON, A.V., 1962. Denture sore mouth: a possible etiology. Brazilian Dental Journal, vol. 1, pp. 357-360.

OHSHIMA, T., IKAWA, S., KITANO, K. and MAEDA, N., 2018. A proposal of remedies for oral diseases caused by Candida: A mini review. Frontiers in Microbiology, vol. 9, pp. 1522. http:// dx.doi.org/10.3389/fmicb.2018.01522. PMid:30038607.

PATIL, S., RAO, R.S., MAJUMDAR, B. and ANIL, S., 2015. Clinical appearance of oral Candida infection and therapeutic strategies. Frontiers in Microbiology, vol. 6, pp. 1391. http:// dx.doi.org/10.3389/fmicb.2015.01391. PMid:26733948.

PUNNIA-MOORTHY, A., 2019. Dental and Oral Conditions in the Very Elderly. In: N. NAGARATNAM, K. NAGARATNAM, G. CHEUK, eds. Advanced age geriatric care. Cham: Springer. http://dx.doi.org/10.1007/978-3-319-96998-5_19

RAO, P.K., 2012. Oral Candidiasis - A review. Scholarly Journal Medical, vol. 2, pp. 26-30.

SANITÁ, P.V., MIMA, E.G., PAVARINA, A.C., JORGE, J.H., MACHADO, A.L. and VERGANI, C.E., 2013. Susceptibility profile of a Brazilian yeast stock collection of Candida species isolated from subjects with Candida-associated denture stomatitis with or without diabetes. Oral Surgery, Oral Medicine, Oral Pathology and Oral Radiology, vol. 116, no. 5, pp. 562-569. http://dx.doi.org/10.1016/j.oooo.2013.07.002. PMid:24055150.

SANTOS, A.L., CARVALHO, I.S., PRATA, J.M., MARTINS, M.B., SOUZA, L.O. and GALDINO, A.C., 2016. Candida albicans involvement in denture-related stomatitis: a serious and real clinical concern. Journal of Infectious Disease Diagnostic, vol. 1, no. 104, pp. 2. http://dx.doi.org/10.4172/2576-389X.1000104.

SHAPIRO, R.S., ROBBINS, N. and COWEN, L.E., 2011. Regulatory circuitry governing fungal development, drug resistance, and disease. Microbiology and Molecular Biology Reviews, vol. 75, no. 2, pp. 213-267. http://dx.doi.org/10.1128/ MMBR.00045-10. PMid:21646428.

SKUPIEN, J.A., VALENTINI, F., BOSCATO, N. and PEREIRACENCI, T., 2013. Prevention and treatment of Candida colonization on denture liners: a systematic review. The Journal of Prosthetic Dentistry, vol. 110, no. 5, pp. 356-362. http://dx.doi.org/10.1016/j. prosdent.2013.07.003. PMid:23998622.

TAY, L.Y., JORGE, J.H., HERRERA, D.R., CAMPANHA, N.H., GOMES, B.P. and ANDRE DOS SANTOS, F., 2014. Evaluation of different treatment methods against denture stomatitis: a randomized clinical study. Oral Surgery, Oral Medicine, Oral Pathology and Oral Radiology, vol. 118, no. 1, pp. 72-77. http:// dx.doi.org/10.1016/j.oooo.2014.03.017. PMid:24908596.

TELLAPRAGADA, C., ESHWARA, V.K., JOHAR, R., SHAW, T., MALIK, N., BHAT, P.V., KAMATH, A. and MUKHOPADHYAY, C., 2014. Antifungal susceptibility patterns, in vitro production of virulence factors, and evaluation of diagnostic modalities for the speciation of pathogenic Candida from blood stream infections and vulvovaginal candidiasis. Journal of Pathogens, vol. 2014, pp. 142864. http://dx.doi.org/10.1155/2014/142864. PMid:25110589.

WARNAKULASURIYA, S., 2019. White, red, and mixed lesions of oral mucosa: A clinicopathologic approach to diagnosis. Periodontology 2000, vol. 80, no. 1, pp. 89-104. http://dx.doi. org/10.1111/prd.12276. PMid:31090142. 